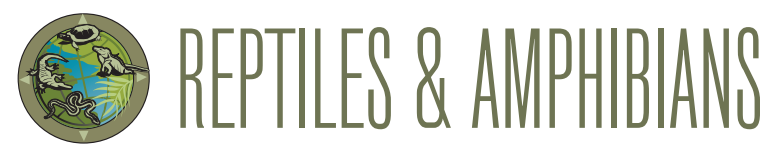

\title{
Unilateral Anophthalmia in an Indian Rock Python, Python molurus (Linnaeus 1758)
}

\author{
Mansi Shah ${ }^{1}$, Jaydeep Maheta ${ }^{2}$, and Sakkira Begum R ${ }^{3}$ \\ ${ }^{1}$ Department of Zoology, Gujarat University, Ahmedabad, Gujarat, India (shahmansi2510@gmail.com [corresponding author]) \\ ${ }^{2}$ Wildlife Care Center, Ahmedabad Forest Department, Gujarat, India (jaydeep2305@gmail.com) \\ ${ }^{3}$ Deputy Conservator of Forests, Social Forestry Division, Sardarnagar, Ahmedabad-382475, India (shahigeneiari@gmail.com)
}

Tndian Rock Pythons (Python molurus), which can reach a 1 maximum length of $8 \mathrm{~m}$ (Whitaker and Captain 2008), occur in Pakistan, India (Assam, Mimachal Pradesh, Jammu and Kashmir, Gujarat, Madhya Pradesh, Kerala, Tamil Nadu, Andhra Pradesh, Karnataka, Maharashtra, Punjab), Nepal, Bhutan, Myanmar, Vietnam, and Sri Lanka (Uetz et al. 2020). These snakes occupy habitats ranging from dry rocky scrub to dense tropical forests, often but not always

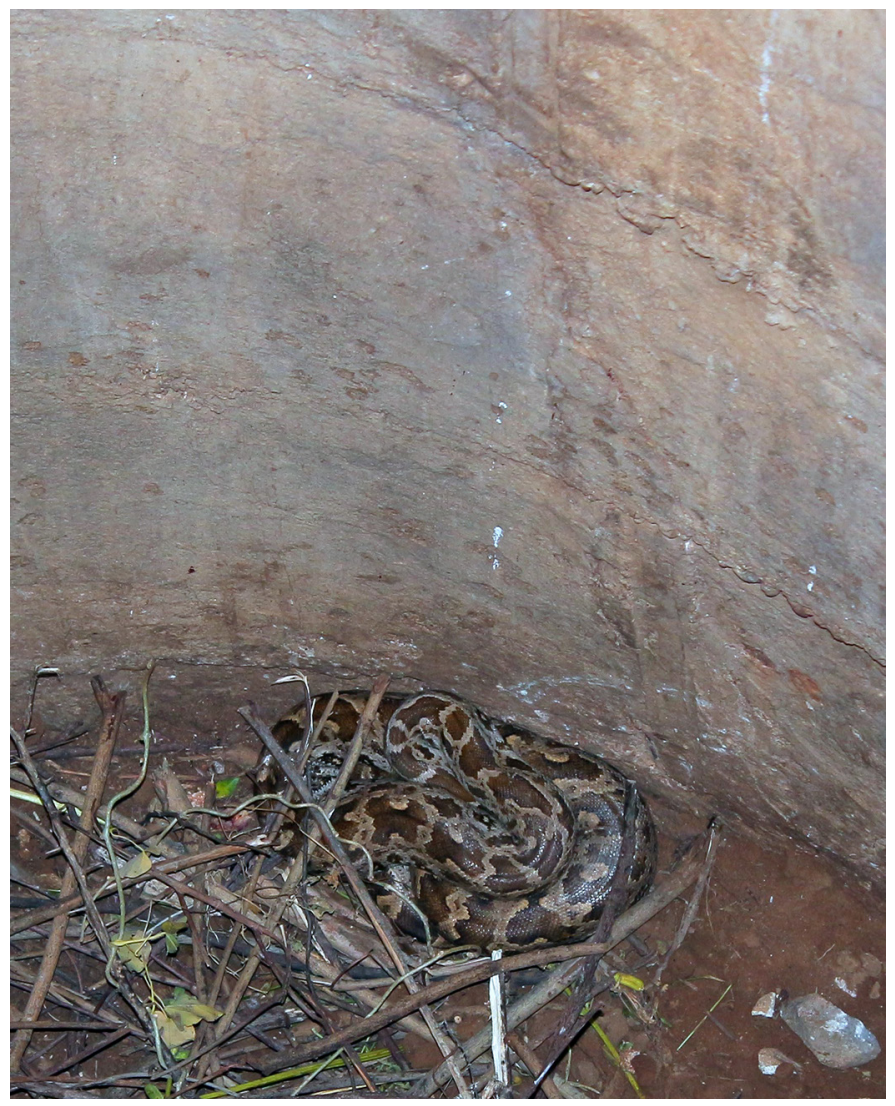

Fig. 1. An Indian Rock Python (Python molurus) rescued from a well near the village of Daduka, Sanand, Ahmedabad, India. Photograph by Jaydeep Maheta.

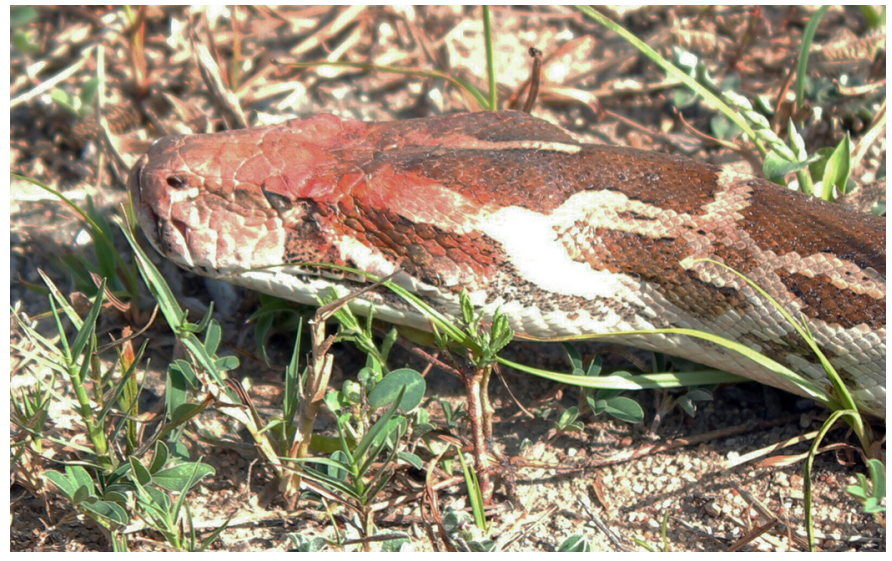

Fig. 2. Anophthalmia in the rescued Indian Rock Python (Python molurus). Photograph by Jaydeep Maheta.

near water, and may occur in human-altered habitats ranging from agricultural land to urban areas (Babar et al. 2019).

In December 2019, we rescued a male Indian Rock Python (Python molurus) from a well near the village of Daduka, Sanand, Ahmedabad, India $\left(22^{\circ} 55^{\prime} 30^{\prime \prime N}\right.$, $\left.72^{\circ} 11^{\prime} 05^{\prime \prime E}\right)$ (Fig. 1). The snake measured $1.62 \mathrm{~m} \mathrm{SVL} \mathrm{(1.90}$ $\mathrm{m} \mathrm{TL}$ ), weighed $7.45 \mathrm{~kg}$, and was missing its left eye (Fig. 2). We found no evidence of injuries and the skin covering the left orbit was normally pigmented. To the best of our knowledge, this is the first report of presumptive unilateral anophthalmia in an Indian Rock Python in nature. After a short period of observation, the python was released into suitable nearby habitat.

Anophthalmia, which can be either unilateral or bilateral, is defined as the congenital total absence of ocular tissue resulting from failure of the primary vesicle to develop or from a complete regression of the optic vesicle (Millichamp et al. 1983). The etiology of anophthalmia is unknown but is thought to be either genetic or environmental (Da Silva et al. 2015). 


\section{Acknowledgements}

We thank the Ahmedabad Forest Department for their guidance; Dr. Raju Vyas for his timely suggestions and guidance as we prepared this manuscript; and Uday Maheta, Rushi Pathak, Rakesh Bharwad, and Jigar Patel for help during fieldwork.

\section{Literature Cited}

Babar, M.E., M.S. Mughal, T. Hussain, M.M. Javed, S. Sherzada, S.A. Khan, and A. Ali. 2019. Biology, habitat and conservation of Indian Rock Python - a brief review. Journal of Animal \& Plant Sciences 29: 349-352.

Da Silva, M.-A.O., M.F. Bertelsen, T. Wang, M. Pedersen, H. Lauridsen, and S. Heegaard. 2015. Unilateral microphthalmia or anophthalmia in eight pythons (Pythonidae). Veterinary Ophthalmology 18, suppl. 1: 23-29. DOI: 10.1111/vop.12198.

Millichamp N.J., E.R. Jacobson, and E.D. Wolf. 1983. Diseases of the eye and ocular adnexae in reptiles. Journal of the American Veterinary Medical Association 183: $1205-1212$.

Uetz, P., P. Freed, and J. Hošek. 2020. The Reptile Database. <http://www.reptiledatabase.org $>$.

Whitaker, R. and A. Captain. 2008. Snakes of India. The Field Guide. Draco Books, Chennai, India. 